\title{
Generic versus specific competencies of entry-level public health graduates: employer's perceptions in Poland, the UK, and the Netherlands
}

Citation for published version (APA):

Biesma, R. G., Pavlova, M. I., Vaatstra, R., van Merode, G. G., Czabanowska, K., Smith, T., \& Groot, W. N. J. (2008). Generic versus specific competencies of entry-level public health graduates: employer's perceptions in Poland, the UK, and the Netherlands. Advances in Health Sciences Education, 13, 325343. https://doi.org/10.1007/s10459-006-9044-0

Document status and date:

Published: 01/01/2008

DOI:

10.1007/s10459-006-9044-0

Document Version:

Publisher's PDF, also known as Version of record

Document license:

Taverne

Please check the document version of this publication:

- A submitted manuscript is the version of the article upon submission and before peer-review. There can be important differences between the submitted version and the official published version of record.

People interested in the research are advised to contact the author for the final version of the publication, or visit the DOI to the publisher's website.

- The final author version and the galley proof are versions of the publication after peer review.

- The final published version features the final layout of the paper including the volume, issue and page numbers.

Link to publication

\footnotetext{
General rights rights.

- You may freely distribute the URL identifying the publication in the public portal. please follow below link for the End User Agreement:

www.umlib.nl/taverne-license

Take down policy

If you believe that this document breaches copyright please contact us at:

repository@maastrichtuniversity.nl

providing details and we will investigate your claim.
}

Copyright and moral rights for the publications made accessible in the public portal are retained by the authors and/or other copyright owners and it is a condition of accessing publications that users recognise and abide by the legal requirements associated with these

- Users may download and print one copy of any publication from the public portal for the purpose of private study or research.

- You may not further distribute the material or use it for any profit-making activity or commercial gain

If the publication is distributed under the terms of Article $25 \mathrm{fa}$ of the Dutch Copyright Act, indicated by the "Taverne" license above, 


\title{
Generic Versus Specific Competencies of Entry-Level Public Health Graduates: Employers' Perceptions in Poland, the UK, and the Netherlands
}

\author{
REGIEN G. BIESMA ${ }^{1, *}$, MILENA PAVLOVA ${ }^{1}$, RINA VAATSTRA ${ }^{2}$, \\ GODEFRIDUS G. VAN MERODE ${ }^{1}$, KATARZYNA CZABANOWSKA ${ }^{3}$, \\ TONY SMITH ${ }^{4}$ and WIM GROOT ${ }^{1,5}$ \\ ${ }^{1}$ Department of Health Organisation, Policy, and Economics, Maastricht University, P.O. Box 616, \\ 6200 MD Maastricht, The Netherlands; ${ }^{2}$ ICLON/Hoger Onderwijs, University of Leiden, The \\ Netherlands; ${ }^{3}$ Institute of Public Health, Collegium Medicum, Jagiellonska University, Krakow, \\ Poland; ${ }^{4}$ ScHARR, Sheffield University, Sheffield, United Kingdom, ${ }^{5}$ Research Center on \\ Schooling, Labor Market and Economic Development, Department of Economics, University of \\ Amsterdam, Amsterdam, The Netherlands (*author for correspondence, E-mail: r.biesma@beoz. \\ unimaas.nl)
}

(Received: 11 June 2006; Accepted 9 October 2006)

\begin{abstract}
Constant changes in society and the public health domain force public health professionals into new roles and the development of new competencies. Public health professionals will need to be trained to respond to this challenge. The aim of this comparative study among Poland, the UK and the Netherlands is to identify competence needs for Master of Public Health graduates entering the labour market from a European perspective. A self-administered questionnaire was sent to employers in the three countries, rating the importance of competency in public health on a master's level. In all three countries, interpersonal competencies, like team working and communication skills, are rated as highly important. However, employers in the UK and Poland generally rate public health specific competencies as much more important than their Dutch colleagues. It is concluded that while public health specific knowledge is providing a useful starting point for entry-level public health professionals, employers increasingly recognise the value of generic competencies such as communication and team working skills. The results suggest a stronger emphasis on teaching methods that encourage active learning and the integration of skills, which is crucial for enhancing graduates' employability, and foster an open attitude to multidisciplinary working, which is essential in modern health care.
\end{abstract}

Key words: employers' perceptions, Europe, graduate education, key competencies, non-medical public health professionals, regression analysis 


\section{Introduction}

Processes like globalisation, advances in life expectancy, rapid growth of knowledge and new public health paradigms (Clark and Weist, 2000; MartinMoreno, 2000; Wright et al., 2000) have changed the work context of public health professionals dramatically over recent years. Not only has the number of health hazards expanded, but the strategies available to deal with them have also increased (Fielding, 1999).

Public health professionals will need to be trained to respond to this challenge. It is argued that a master's level training in public health is one essential component, but on-the-job experience, training and continuous education are also important to respond to this challenge (Ibrahim et al., 1995). Learning by doing through work experience is increasingly recognised as an important channel for acquiring the new skills that employers themselves demand (Rosen, 1976; Eraut, 2001; Stasz, 2001) and this means that learning does not stop after leaving initial education. However, it is argued that the extent, to which public health professionals are able to acquire or improve competence, depends to a large extent to the level and type of competencies acquired in initial education (Heijke et al., 2003).

Up until recently masters degrees in public health have been structured around areas such as epidemiology, health policy, health promotion, health management, environmental health, human biology and health economics (Fineberg et al., 1994; Davies, 1996). Nowadays, courses also highlight the importance of competence in such areas as: statistical analysis and the use of computer programmes; the ability to access, manage and work with information; the ability to present and disseminate information in an effective manner; interview and communication skills; sensitivity to health inequalities; and social skills (Giles, 2001).

This paper provides new insights on the role of generic and public health specific competencies during the transition from education to the labour market in three European countries. For the purpose of this paper, we define generic competencies as a combination of higher cognitive (academic) and interpersonal skills that are broadly transferable across work settings. The term 'specific competencies' in our paper refers to the specific knowledge and skills needed in a profession, such as theoretical knowledge and knowledge of methods and procedures in public health (Stasz, 2001; Heijke et al., 2003).

In view of these definitions, several studies have identified the key competencies required by public health professionals. However, previous studies on key competencies yielded only descriptive findings. One group of studies identified lists of universal public health competencies using qualitative approaches, such as Delphi group rounds and focus groups (Sorensen and Bialek, 1991; Ibrahim et al., 1995; Clark and Weist, 2000; Potter et al., 2000; Wright et al., 2000; Allegrante et al., 2001; El Ansari 
et al., 2003a; Kreitner et al., 2003). Although qualitative approaches, like focus groups, are very useful in identifying perceived key competencies, these approaches preclude firm conclusions and have limited representativeness (Green and Kreuter, 1991). A second group of studies assessed the professional development needs of public health professionals by survey. However, these studies focused either on a single country (Chauvin et al., 2001), a specific context, such as primary care (Freudenstein and Yates, 2001; Brocklehurst and Rowe, 2003), or on self-assessed competency (Bartee et al., 2003). Moreover, these studies were focusing on universal competencies of the public health workforce as a whole, including nurses, laboratory staff and physicians.

The study presented here goes one step further than simply reflecting the current status of all the key competencies that are needed in the public health workforce. We asked employers in Poland, the UK and the Netherlands to rank key competencies of non-medical public health graduates. We were also interested whether contextual or situational factors influenced the preferences for particular competencies.

Our paper aims to compare the importance of the field-specific and generic competencies for the employability of entry-level public health graduates in Europe. We defined an entry-level public health professional as a Masters graduate who has been working in a public health organisation for less than a year. We focused on this group of public health professionals to examine whether there was a match between the competencies gained in education and those required in the public health field. Through targeting this group we also attempted to avoid the influence of competencies that had been acquired on the job.

\section{Background of the Study}

\section{THE PUBLIC HEALTH CONCEPT}

Public Health is often defined as 'the science and art of promoting health, preventing disease and prolonging life through the organised efforts of society' (Acheson, 1988). However, the concept is broad and used in a variety of ways. It not only refers to an activity, a discipline, an infrastructure, a scientific field of expertise, a philosophy and a sphere of work, but also to groups of professionals working in this field (Beaglehole and Dal Poz, 2003; Rooijmans and Benneker, 2003).

The development of the public health profession has followed developments in the understanding of what public health is. Until the 1990's, the term 'public health' was rather narrowly defined, focusing mainly on epidemiological issues in the public health area (Frenk, 1999). At that time, the public health profession was primarily associated with the area of social 
medicine. However, as the broader, multidisciplinary concept of public health has evolved (named the new public health), the public health profession has also needed to be redefined (de Leeuw, 1995). Nowadays, the public health workforce consists of professionals from a wide range of disciplines, including physicians, epidemiologists, health managers, occupational health specialists and health educators (Beaglehole and Dal Poz, 2003). The new public health has expanded to virtually every sector in society, from education to architecture and relies on the close interaction of public health professionals (Rowitz, 1999; Clark and Weist, 2000). Although the importance of the new public health is internationally recognised, it has not yet been adequately operationalised at country level. Many governing institutions do not have a clear definition of responsibilities and an explicit recognition of the central role of the public (Heller et al., 2003). Unsurprisingly, this lack of clarity over the nature and scope of public health has resulted in confusion about the nature and scope of the public health profession as well.

In Europe, the attempt to define the public health concept and the public health profession have proved problematic because interpretations of public health vary significantly depending on the historical, cultural and political conditions within individual countries' (Bury, 1999; McKee and Jacobson, 2000). Even at the EU level, the public health concept is rather vague (Cavallo, 1998). It fails to account for the societal component of public health and does not provide a comprehensive framework for the analysis of public health issues. This is mainly because the member states put low priority on the development of a unified definition of public health (Mossialos and Permanand, 2000).

\section{Public health workforce in Europe}

All European countries have trained public health workers in the context of their own public health systems. These national differences in how public health is organised broadly fit into three categories (Davies, 1996; McKee and Jacobson, 2000; Mossialos and Permanand, 2000).

The first category consists of countries with insurance-based health care systems. These systems are characterised by a strong sense of individual responsibilities for health. This ethos prevails when it comes to defining the roles, functions and responsibilities in the public health area. An example is the Netherlands, where public health duties are executed by both private non-profit organisations and municipalities, with supervision and monitoring at regional and national level by the Health Care Inspectorate (European Observatory on Health Systems and Policies, 2005). Municipalities have the statutory responsibility to govern public health (Plochg et al., 2006). Originally, public health in the Netherlands was the domain of physicians with a specialisation in social medicine, who successfully amongst other 
things introduced vaccinations and pushed back unhealthy working conditions (Rooijmans and Benneker, 2003). However, since the mid 80s, disciplines such as epidemiology have become increasingly important adding a new scientific dimension to the public health field. Since then, university-based public health bachelor and masters programs have emerged, whose curricula mirror this broad understanding, including studies ranging from biological health sciences, to behavioural and social health sciences (Rooijmans and Benneker, 2003). Public health education in the Netherlands, at institutions like the Faculty of Health Sciences in Maastricht University, has been at the forefront of developing problem-based learning to encourage active learning and the integration of skills.

The second category of public health systems is those countries with tax-funded health care systems. In these systems, public health is typically perceived as distinct from curative medicine, and the provision of public health services is seen as a government duty rather than an individual responsibility. An example of this type of system is the UK where public health falls under the responsibility of the National Health Service (NHS). Health protection, health promotion and screening programmes have traditionally been the three basic strands to public health in the UK. As in the Netherlands, senior public health posts in the UK NHS were traditionally exclusively the domains of medical doctors (Evans, 2003). In the mid 90's however, radical health care reforms and changing health demands led to new roles in public health and challenged the traditional domination of the medical profession (Scally, 1996; El Ansari et al., 2003b). Most significantly the notion emerged that the performance of the health system should be linked to the health status of the population. Thus, the NHS has needed to work in partnership with other agencies and sectors, to use community-based approaches and target risk groups at primary and secondary prevention. Presently, multidisciplinary non-medical public health functions still need to be developed, but there is a lack of common understanding of what this encompasses (Scally, 1996; El Ansari et al., 2003b). The UK Faculty of Public Health Medicine (FHPM) now accepts non-medical public health specialist pathways, although to date the majority of postgraduate training in public health is aimed at medical doctors (El Ansari et al., 2003b; Beaglehole and Bonita, 2004) and the primary mode of qualification of specialists is still the FPHM examinations. The undertaking of a Masters in Public Health (MPH) graduates in the UK is often a mid career activity.

The third category of public health systems can be found in the former socialist countries. Until recently, these countries relied on a unified approach to public health characterised by a combination of basic curative and preventive services under strong government control. Since 1990, these countries have turned away from central planning and introduced rigorous 
market reforms, which extend to the health care sector (Leven, 2005). Poland is an example of this type of system. Poland traditionally focused on sanitary inspection for the control of infectious disease with considerable success. Nowadays, public health in Poland is in a phase of transition due to the rapidly changing health demands and the fast introduction of reforms (Burazeri et al., 2005). A prime example is health promotion, which was previously left to sanitary and hygiene institutions at regional level, but nowadays has developed at the national level and is seen as an important part of health policy (European Observatory on Health Systems, 1999). As a former communist country, public health research and training was traditionally located in medical universities, often within departments of hygiene or of social medicine (De Leeuw, 1995). Training based on the new public health is emerging in Poland and a broader range of teaching strategies, such as encouraging students to give presentations of their work and small-group projects are being introduced. However, it is argued that structural barriers within the old communist public health training system are making change to training based on new public health concepts challenging (Burazeri et al., 2005).

The three countries given as examples above are all included in this study. Whilst they have very different Public Health systems, what they do have in common is that there has been a policy driven movement towards multidisciplinary public health function. What is unclear in all three countries however, is what competencies are required from Masters in Public Health graduates to deliver these common policy aspirations. That is the question that is addressed in this study.

\section{Methods}

\section{DATA COLLECTION}

This study is a part of a large project designed to improve the employability of MPH graduates in Poland, the UK and the Netherlands. For the purpose of the project a questionnaire was developed to elicit from public health employers the relative importance of key competencies.

The key competencies were selected based on a literature review, and focus group interviews. This process has been described in detail elsewhere (Czabanowska, 2002; Smith et al., 2002). Briefly however, aggregation of a comprehensive list led to the identification of 67 competencies. Qualitative approaches further reduced the list of competencies to 34 public health competence-items that employers consider essential for entry-level public health professionals. These 34 competencies included both public health-specific and generic competencies. The cluster defined as generic competencies consists of both higher cognitive (academic) as well as 
interpersonal competencies. Higher cognitive competencies are a combination of learning abilities, analytical skills and problem-solving abilities that are broadly transferable to various contexts (Heijke et al., 2003). Interpersonal competencies are those utilised in the process of accomplishing a task, such as communication and team working skills. The second cluster, defined as public health specific competencies, are competencies related to gathering and understanding theoretical knowledge as well as methods and procedures specific to public health practice. Respondents were asked to rate how important it is for entry-level public health graduates to possess the 34 competencies for their current job on a five-point scale; (1) unimportant; (2) desirable; (3) important; (4) very important; and (5) excellent. Only one negative category was used as it was expected that respondents would tend to ignore negative evaluations (Biesma et al., 2002).

Additionally, questions about the socio-demographic characteristics of respondents were included, such as their educational background, position and the type of health care organisation they work for. The data collection procedure was piloted in Poland for content validity using 22 experts who represented various groups of employers. While the differences in public health concept, profession and educational system in the Netherlands, the UK and Poland have been shown in this paper, we did not give a definition of public health in the questionnaire. Rather, respondents, in all countries, were given freedom to interpret the term 'entry-level public health professional' according to their own frame of reference. The reason for this was that including a definition of public health in the questionnaire could have prompted respondents to rate the competencies implicit in such a definition as more important (De Leeuw, 1999).

\section{RESPONDENTS AND SETTINGS}

Information about the socio-demographic characteristics of the respondents can be found in Table I. In the Netherlands and Poland, a random stratified sample was drawn from a database of around 1000 public health employers per country. The aim was to represent various types of public health organisations, including residential care organisations; community health care organisations; sanitary inspection; insurance companies; and governmental organisations. In the UK, it was not possible to draw a random sample due to a system wide reorganisation in public health services at the time of the survey. A stratified sample of 167 public health professionals was selected from a database of around 700 public health professionals representing both organisations with solely public health duties and organisations who have a partial role in furthering the public health agenda through their work with communities. 
Table I. Respondents' characteristics of the sample of Dutch, British and Polish employers $(n=548)$

\begin{tabular}{ll}
\hline Characteristics & Percentage (number)* \\
\hline 1. Type of public health organisation & \\
Application oriented & $38.1 \%(209)$ \\
Policy oriented & $61.3 \%(336)$ \\
2. Position within the organisation & \\
Director of a public health organisation & $41.6 \%(268)$ \\
Manager in a public health organisation & $33.8 \%(185)$ \\
Staff member in a public health organisation & $17.3 \%(95)$ \\
3. Country of origin & \\
Poland & $56.8 \%(311)$ \\
UK & $9.5 \%(52)$ \\
Netherlands & $33.8 \%(185)$ \\
\hline
\end{tabular}

*Due to missing values, totals may not add to $100 \%$.

For the cross-country comparison, the different type of public health organisations were recoded into organisations oriented at developing public health policy and public health action oriented organisations. Employers were recoded into directors, managers and staff members. The overall response rate was $40 \%$, which is regarded as acceptable when comparing to other mailed surveys, especially among a group of employers who are difficult to reach (Halbert et al., 1998).

\section{DATA ANALYSIS}

In order to reduce the number of competencies for analysis, a factor analysis was performed to identify the common underlying factors of the 34 competence-items. Based on the criterion of eigenvalues greater than one, seven factors were extracted (see Table II). The seven factors combined explain $63 \%$ of the variance. We set the cut-off for factor loadings at 0.45 (20\% overlapping variance). The following factors are identified: (1) public health specific; (2) teamwork and communication; (3) professionalism; (4) advocacy, negotiation and conflict management; (5) project management; (6) deal and respond to changes; and (7) collegiality and reflection.

Then, for each factor, we calculated a sum score for both required and possessed skill level. We divided the sum score by the total number of items per factor and recoded the scores into the five original categories, with 1 and 5 as the minimum and maximum value. To determine a relative rank order of the seven key competencies per country, a series of non-parametric tests was 


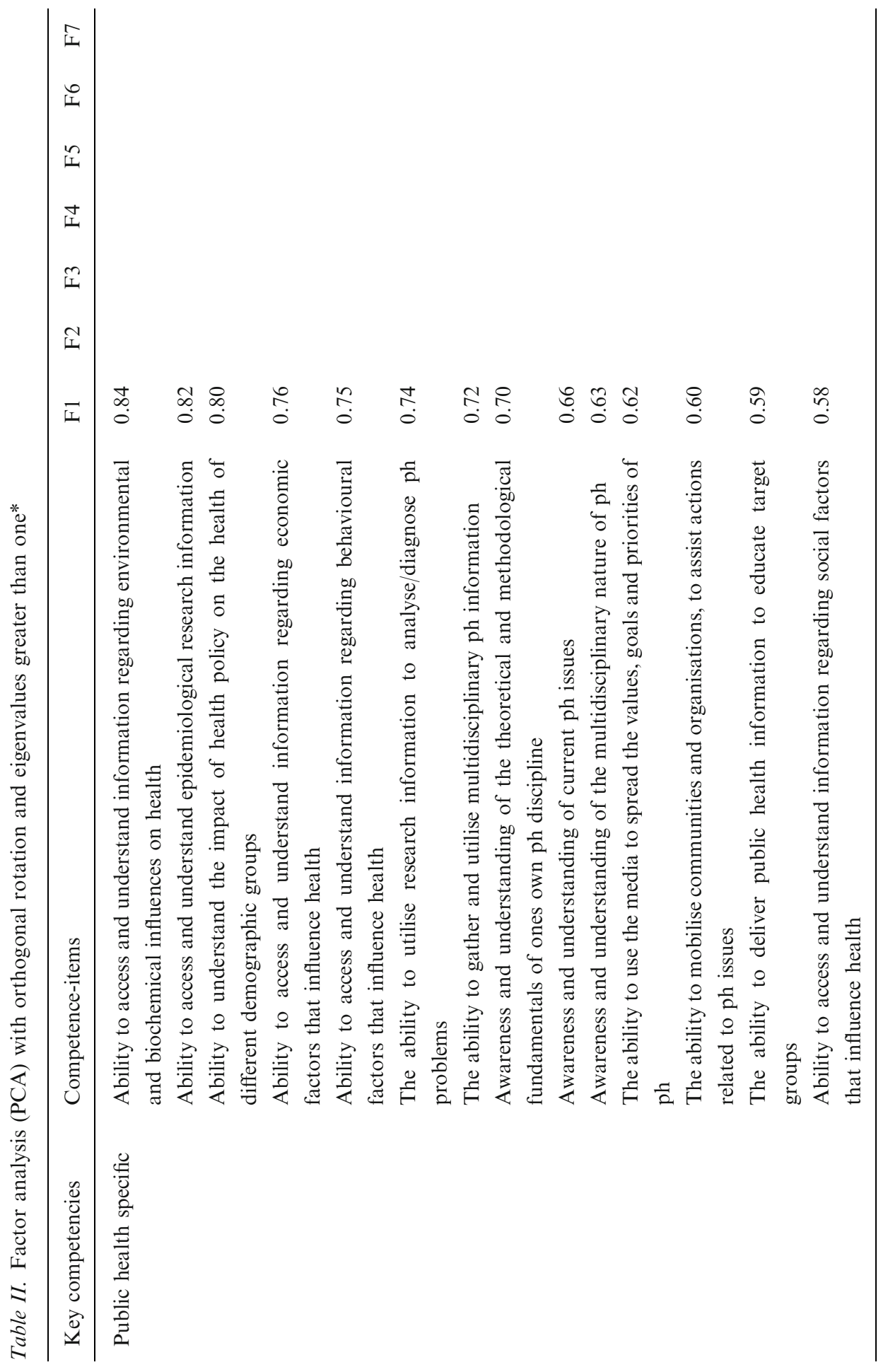




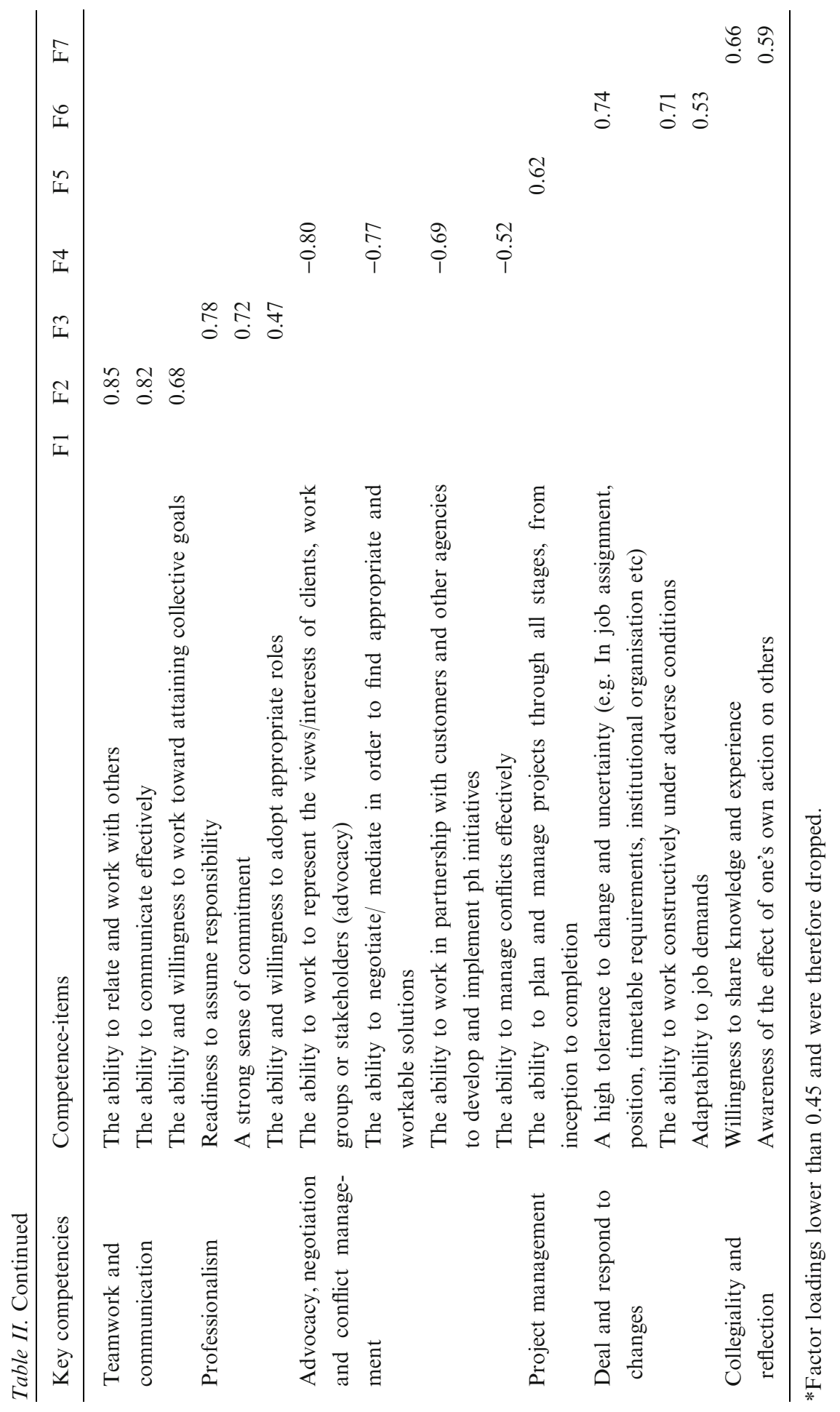


performed. A sign test was used to analyse whether the median ratings of each pair of competencies significantly differed and if they did differ, which one was ranked higher, or lower. Where there were no significant differences, the competencies were assigned to the same rank level. Finally, an ordered logit regression was conducted to analyse the impact of various sociodemographic factors on the rating of each of the selected key competencies. In particular, whether preferred competencies differed with regards to country of origin, type of public health organisation, and the position of the respondent.

\section{Results}

\section{RATING OF KEY COMPETENCIES}

The results of the relative rating of the key competencies are shown in Table III. The respondents in all samples confirmed that key competencies are essential for masters level public health graduates entering the public health field. The mean score for each key competence was consistently at or above 3.5 on a five-point response scale.

Table III. Descriptive statistics and rank order of the key competencies per country

\begin{tabular}{|c|c|c|c|c|c|c|c|c|c|c|}
\hline \multirow[t]{2}{*}{ Factors } & \multirow{2}{*}{$\begin{array}{l}\text { Key } \\
\text { competencies }\end{array}$} & \multicolumn{3}{|c|}{ Poland } & \multicolumn{3}{|l|}{ UK } & \multicolumn{3}{|c|}{ The Netherlands } \\
\hline & & Mean & $\mathrm{SD}$ & Ranking & Mean & $\mathrm{SD}$ & Ranking & Mean & $\mathrm{SD}$ & Ranking \\
\hline $\mathrm{F} 1$ & Public health specific & 3.73 & 0.72 & 4 & 3.82 & 0.53 & 4 & 2.68 & 0.71 & 7 \\
\hline $\mathrm{F} 2$ & $\begin{array}{l}\text { Teamwork and } \\
\text { communication }\end{array}$ & 4.05 & 0.73 & 2 & 4.44 & 0.67 & 1 & 4.15 & 0.64 & 1 \\
\hline F3 & Professionalism & 4.28 & 0.62 & 1 & 3.84 & 0.58 & 4 & 3.44 & 0.56 & 3 \\
\hline $\mathrm{F} 4$ & $\begin{array}{l}\text { Advocacy, negotiation } \\
\text { and conflict } \\
\text { management }\end{array}$ & 3.65 & 0.72 & 6 & 3.88 & 0.65 & 4 & 3.26 & 0.72 & 6 \\
\hline F5 & Project management & 3.82 & 0.94 & 3 & 3.67 & 0.88 & 7 & 3.31 & 1.05 & 3 \\
\hline F6 & $\begin{array}{l}\text { Deal and respond } \\
\text { to changes }\end{array}$ & 3.71 & 0.71 & 4 & 4.04 & 0.71 & 2 & 3.49 & 0.64 & 3 \\
\hline F7 & $\begin{array}{l}\text { Collegiality and } \\
\text { reflection }\end{array}$ & 3.59 & 0.73 & 7 & 3.98 & 0.70 & 2 & 3.63 & 0.67 & 2 \\
\hline
\end{tabular}

Note: Based on the sign test, we find for Poland that factors 1 and 6; factors 6 and 4; factors 1 and 4; and factors 4 and 7 are not statistically different. For the UK, factors 6 and 7; factors 7 and 4; factors 6 and 4; factors 4 and 3; factors 3 and 1; factors 4 and 1; and factors 1 and 5 are not statistically different. For the Netherlands, factors 6 and 3; factors 3 and 5; factors 6 and 5; and factors 5 and 4 are not statistically different. 
Respondents in Poland rated the following key competencies as highest: 'professionalism', 'team work and communication' and 'project management'. These were followed by 'public health specific competence' and 'dealing and responding to changes'. 'Collegiality and reflection' was rated as least important.

UK public health employers rated the key competencies for public health graduates slightly differently. 'Teamwork and communication', 'deal and respond to changes' and 'collegiality and reflection' were the top ranked key competencies. 'Project management' was considered least important for public health graduates entering the labour market.

In the Netherlands, the mean scores of the competence ratings were generally lower than in the UK and Poland. 'Teamwork and communication' and 'collegiality and reflection' were the top ranked key competencies. Interestingly, public health specific competency was least important.

\section{DETERMINANTS OF THE RATED KEY COMPETENCIES}

The regression coefficients of seven ordered logit models of demographic variables on the importance of key competencies are presented in Table IV. The models were successfully tested on the proportional odds assumption. In each model, the dependent variable is the rating on the key competence measured on a 5-point scale (ordered).

Employers in both Poland and the UK value the importance of a number of key competencies statistically significantly higher than their colleagues in the Netherlands. These are: 'public health specific'; 'advocacy, negotiation and conflict management'; 'project management' and 'to deal and respond to changes'. However, the importance of 'teamwork and communication,' and 'collegiality and reflection' is higher in the UK compared to the other two countries.

Further, the key competence 'advocacy, negotiation and conflict management' was ranked more important by employers working in policy oriented health organisations than by those working in action oriented public health organisations. Interestingly, managers rated competence in 'dealing and responding to changes' statistically significantly lower than directors and staff members.

However, some of the ordered logit models estimating the importance of key competencies showed low explained variance. This indicates that other variables, that are not included in this survey, determine employers' preferences for key competencies. Personal characteristics of the employer, as well as demographic, economic, political and institutional factors could all have affected the competence ratings. 


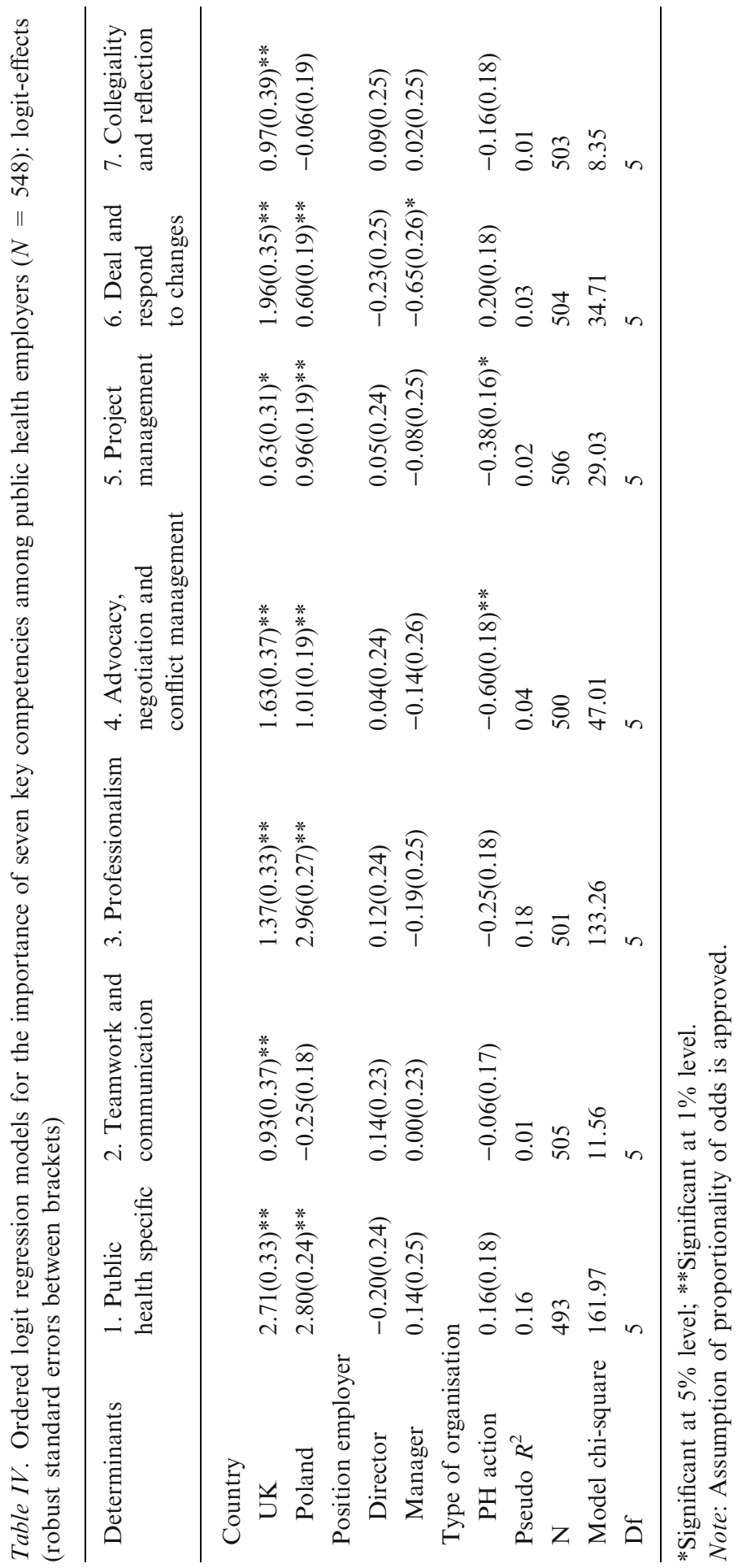




\section{Discussion}

The results of this comparative study show that employers in all three countries value possession of the key competency 'teamwork and communication' by public health graduates as highly important. Previous studies in labour economics confirm that 'communication and team working skills' are widely recognised as one of the most important skills needed by current workers (Green et al., 2001; Stasz, 2001). Working collectively and initiating and working in partnership with organisations, groups and individuals are fundamental to public health activities (Clark and Weist, 2000; El Ansari et al., 2003a).

Perhaps the most surprising result of the study is that public health specific competencies, such as 'the ability to understand public health specific information,' were not ranked as most important by employers in the three countries. Stasz (2001) had similar results, finding that employers regard generic skills and work-based attitudes as more important than academic or technical knowledge. A choice experiment to elicit the relative importance of competencies among a sample of Dutch employers confirms that advanced generic competencies are valued more highly than public health specific competencies (Biesma et al., 2006). Others suggest that the complex demands of the public health field require professionals with problem solving and creative thinking capabilities rather than the ability to reproduce factual knowledge (Fineberg et al., 1994; Satish et al., 2001).

This study tells us something about the relative importance that public health employers place on these competencies for entry-level graduates. However, employers were only able to choose from the list of competencies given and it might be that competencies not included in the study could be more or less important than the one's studied here. There is also an assumption that employers know what competencies graduates need, while it may be that employers rarely think in depth about specific competencies. This argument may be supported by theories of labour demand, which assume that employers try to maximise profits and are therefore interested in productivity-related characteristics (van Beek et al., 1997). Arrow's filtering theory (1973) proposes that employers have incomplete information on the true productivity or workers and therefore use easily identifiable worker attributes as causal. Further, as it has been mentioned before, public health employers are facing rapid and continuous changes due to the globally growing knowledge economy, making the match between specific competencies and job tasks difficult. It could be that employers increasingly tend to value competencies that are broadly transferable, such as communication and teamwork, learning abilities and flexibity (Saunders and Machell, 2000). However, in our study, we did not investigate, whether these competencies are simply 
proxies for, or perhaps contributors to the acquisition of, unmeasured skills or are valued as such by employers (Bowles et al., 2000).

Another issue is to what extent generic and specific competencies can be separated. Bloom (1956) describes a taxonomy of higher cognitive competence by the following levels: knowledge, comprehension, application, analysis, synthesis and evaluation. In view of this theory, theoretical knowledge of public health would be a necessary condition for the development of higher cognitive skills that provide the ability to deal with new problems and enable one to further develop competencies (Biesma et al., 2006). This could also be a reason why public health specific competence was ranked lower.

Although the importance of competencies in the three countries is generally consistent, there are also important differences. 'Public health specific competence'; 'professionalism'; 'advocacy, negotiation and conflict management'; 'project management skills'; and 'the competence to deal and respond to changes' are valued significantly higher in Poland and in the UK than in the Netherlands. A partial explanation could be found in the countryspecific context. Both the UK and Poland have recently undergone radical health care reforms and changing professional roles. Changes in the Dutch health care system are characterised by a long history of consensual processes and policy debate and are therefore more gradual. The fact that multidisciplinary public health evolved in the 80's in the Netherlands, while it was only introduced in the UK and Poland in the mid 90's may also be a factor. The professional status of non-medical public health specialists in the UK and Poland is gaining formal recognition, but still faces substantial challenges to acceptance. Thus, the diffusion of the new public health paradigm and the accompanying process of professionalisation of non-medical public health professionals varies across countries according to the characteristics of national policies and systems (Hashimoto et al., in press).

An acknowledged difficulty in surveys where explicit questions are asked is the issue of socially desirable answers. People tend to find every item important, especially those items they believe that the researcher or society finds important (Van Beek et al., 1997). However, social desirability bias in this survey seems unlikely, as public health competence was not top ranked. Another source of possible bias is selection bias. Both the Netherlands and Poland have drawn a random sample of a nationwide database of public health employers minimizing the possibility for differential selectivity. However, the UK followed a non-random selection procedure, making generalisation more difficult. Although the results must be interpreted with caution, the UK results are still useful for providing directions. Furthermore, as outlined above, other studies have reported similar results, which are an indication of the overall convergent validity of our findings. 


\section{CONCLUSIONS}

This study contributes to the discussion on the role of generic and field specific competencies during the transition from initial education to the rapidly changing public health field. The results are relevant for the adjustment of training in public health around Europe. This study shows that, while public health specific competence provides a useful starting point for entry-level public health professionals, employers increasingly value generic competencies, such as communication and team work. Additionally, the question is asked whether skill requirements are universal and change at the same pace across countries. The cross-country comparison suggests that the competence needs of public health graduates do not only depend on public health tasks he/she has to carry out, but also on other variables that are not included in this study. For instance, the diffusion of the new public health paradigm and the accompanying introduction of non-medical public health professionals in a specific country, including educational pathways, may also account for employers' preferences.

Future research on key competencies is needed that builds upon our work to investigate to what extent cultural and context-specific differences between countries influence employer's preferences. Furthermore, problems of concept are stimulating a deeper inquiry into the type and level of competencies required for public health professionals (Fineberg et al., 1994).

\section{RECOMMENDATIONS FOR PUBLIC HEALTH POLICY}

The conclusions of this study indicate that strategies to integrate specific knowledge with generic competencies are important for preparing graduates for dealing with changing and complex public health demands. One approach is problem-based learning that encourages active learning and integration of skills. This is crucial for enhancing graduate employability, and could help foster and the open attitude to multidisciplinary working which is essential in modern health care.

- A key development in public health training across countries could be the rapidly changing information technology that makes classroom distance learning possible. Instead of a public health professional travelling to a learning site, the educational content will be taken to the learner (Ibrahim et al., 1995).

- An innovative approach that has been recently developed is online PBL, which has the potential to facilitate active learning and the integration of skills amongst public health professionals across countries.

- Professionalisation is needed to increase the recognition and visibility of nonmedical public health specialists (Sommer and Akhter, 2000) and flatten the road for public health graduates entering the field. 


\section{Acknowledgement}

This study was funded by the European Commission Leonardo da Vinci programme ( $\mathrm{PL} / 00 / \mathrm{B} / \mathrm{F} / \mathrm{PP} / 140155)$. The authors would like to acknowledge all members of the Leonardo project team for their cooperation and invaluable contributions during the Leonardo survey. Furthermore, the authors wish to thank Sandra Boessen for her useful comments on previous drafts of the article.

\section{References}

Acheson, D. (1988). Independent Inquiry into Inequalities in Health London: HM Stationary Office.

Allegrante, J.P., Moon, R.W., Auld, M.E. \& Gebbie, K.M. (2001). Continuing-education needs of the currently employed public health education workforce. American Journal of Public Health 91(8): 12301234.

Arrow, K.J. (1973). Higher education as a filter. Journal of Public Economy 2(3): 193-216.

Bartee, R.T., Winnail, S.D., Olsen, S.E., Diaz, C. \& Blevens, J.A. (2003). Assessing competencies of the public health workforce in a frontier state. Journal of Community Health 28(6): 459-469.

Beaglehole, R. \& Bonita, R. (2004). Public Health at the Crossroads - Achievements and Prospects Cambridge: Cambridge University Press.

Beaglehole, R. \& Dal Poz, M.R. (2003). Public health workforce: challenges and policy issues. Human resources for Health $\mathbf{1}(4)$ : 1-7.

Biesma, R.G., Pavlova, M., Merode Van, G.G. \& Groot, W. (2006). Using conjoint analysis to estimate employers preferences for key competences of master level dutch graduates entering the public health field. Economics of Education Review (in press).

Biesma, R.G., Pavlova, M., Groot, W., Vaatstra, H.F. \& Merode, G.Van (2002). Measuring employers' preferences for competences of junior public health professionals. Zdrowie Publiczne 112(2): 175-181.

Bloom, B.S. (1956). Taxonomy of the Educational Objectives New York: David McKay.

Bowles, S., Gintis, H. \& Osborne, M. (2000). The Determinants of Earnings: Skills, Preferences, and Schooling. Working Papers 2000-07, University of Massachusetts Amherst, Department of Economics.

Brocklehurst, N.J. \& Rowe, A. (2003). The development and application of a public health skills assessment tool for use in primary care organisations. Public Health 117(3): 165-172.

Burazeri, G., Laaser, U., Bjegovic, V. \& Georgieva, L. (2005). Regional collaboration in public health training and research among countries of south eastern europe. European Journal of Public Health 15(1): 97-99.

Bury, J.A. (1999). Training public health resources for a changing world. Internet Journal of Public Health Education 1: C61-81.

Cavallo, F. (1998). Public Health Education and Training in Europe Turin: NHV report.

Chauvin, S.W., Anderson, A.C. \& Bowdish, B.E. (2001). Assessing the professional development needs of public health professionals. Journal of Public Health Management Practice 7(4): 23-37.

Clark, N.M. \& Weist, E. (2000). Mastering the new public health. American Journal of Public Health 90(8): $1208-1211$.

Czabanowska, K. (2002). The Leonardo da Vinci project 'improved employment for public health graduates' in the context of international studies. Zdrowie Publiczne 112(2): 293-295.

Davies, A.M. (1996). Training professionals for the new public health. Public Health Review 24: $205-211$.

De Leeuw, E. (1995). European schools of public health in state of flux. Lancet 345(8958): 1158-1160.

De Leeuw, E. \& Voermans, P. (1999). The (de) medicalization of public health training. Internet Journal of Public Health Education 1: B28-43.

El Ansari, W., Russell, J., Spence, W., Ryder, E. \& Chambers, C. (2003a). New skills for a new age: leading the introduction of public health concepts in healthcare curricula. Public Health 117(2): 77-87.

El Ansari, W., Russell, J. \& Wills, J. (2003b). Education for health: case studies of two multidisciplinary $\mathrm{mph} / \mathrm{msc}$ public health programmes in the uk. Public Health 117(5): 366-376. 
Eraut, M. (2001). The role and use of vocational qualifications. National Institute Economic Review 0(178): $88-98$.

European Observatory on Health Systems (1999). Health Care Systems in Transition: Poland Copenhagen: WHO Regional Office for Europe.

European Observatory on Health Systems and Policies (2005). Health Care Systems in Transition Summary: The Netherlands. .

Evans, D. (2003). 'Taking public health out of the ghetto': the policy and practice of multi-disciplinary public health in the united kingdom. Social Science \& Medicine 57(6): 959-967.

Fielding, J.E. (1999). Public health in the twentieth century; advance and challenges. Annual Review of Public Health 20: xiii-xxx.

Fineberg, H.V., Green, G.M., Ware, J.H. \& Anderson, B.L. (1994). Changing public health training needs: professional education and the paradigm of public health. Annual Review of Public Health 15: 237-257.

Frenk, J. (1999). What's in a name: editorial. Bulletin of the World Health Organization. The International Journal of Public Health 77(2): 101.

Freudenstein, U. \& Yates, B. (2001). Public health skills in primary care in south west England - a survey of training needs, obstacles and solutions. Public Health 115(6): 407-411.

Giles, M. (2001). Public Health Degree Courses: Structure, Content, and Teaching Methods Sheffield: ScHARR, Sheffield University.

Green, F., Ashton, D. \& Felstead, A. (2001). Estimating the determinants of supply of computing, problem-solving, communication, social, and teamworking skills. Oxford Economic Papers 3: 406-433.

Green, L.W. \& Kreuter, M.W. (1991). Health Promotion Planning: An Educational and Environmental Approach Mountain View: Mayfield Publishing Company.

Halbert, R., Bokor, A., Castrence-Nozareno, R., Parkinson, M.D. \& Lewis, C.E. (1998). Competencies for population-based clinical managers - a survey of managed care medical directors. American Journal of Preventive Medicine 15(1): 65-70.

Hashimoto, H., Noguchi, H., Heidenreich, P., Saynina, O., Moreland, A., Miyazaki, S., Ikeda, S., Kaneko, Y. \& Ikegami, N. The diffusion of medical technology, local conditions, and technology reinvention: a comparative case study on coronary stenting. Health policy 79(2-3): 221-230.

Heijke, H., Meng, C. \& Ris, C. (2003). Fitting to the job: the role of generic and vocational competencies in adjustment and performance. Labour Economics 10(2): 215-229.

Heller, R.F., Heller, T.D. \& Pattison, S. (2003). Putting the public back into public health. Part i. A re-definition of public health. Public Health 117(1): 62-65.

Ibrahim, M.A., House, R.M. \& Levine, R.H. (1995). Educating the public health work force for the 21st century. Fam Community Health 18(3): 17-25.

Kreitner, S., Leet, T.L., Baker, E.A., Maylahn, C. \& Brownson, R.C. (2003). Assessing competencies and training needs for public health professionals managing chronic disease prevention programs. Journal of Public Health Management and Practice 9(4): 284-290.

Leven, B. (2005). Corruption and reforms: a case of Poland's medical sector. Communist and PostCommunist Studies 38: 447-455.

Martin-Moreno, J. (2000). Training and professionalisation in public health: it is really needed?. Internet Journal of Public Health Education 2: A1-6.

Mckee, M. \& Jacobson, B. (2000). Public health in Europe. The Lancet 356(9230): 665-670.

Mossialos, E. \& Permanand, G. (2000). Public Health in the European Union: Making it Relevant London: LSE Health, London School of Economics \& Political Science.

Plochg, T., Delnoij, D.M.J., Hogervorst, W.V.G., Van Dijk, P., Belleman, S. \& Klazinga, N.S. (2006). Local health systems in the 21 st century: who cares? - an exploratory study on health system governance in Amsterdam. European Journal of Public Health 16: 559-564.

Potter, M., Pistella, C.L., Fertman, C.I. \& Dato, V.M. (2000). Needs assessment and a model agenda for training in public health workforce. American Journal of Public Health 90: 1294-1296.

Rooijmans, H.G.M. \& Benneker, H.W. (2003). Advies kennisinfrastructuur public health: Kennisverwerving en kennistoepassing Den Haag: Raad voor Gezondheids Onderzoek.

Rosen, S. (1976). A theory of life earnings. Journal of Political Economy 84: S45-S67.

Rowitz, L. (1999). The mystery of public health workforce development. Journal of Public Health Management and Practice 5(3): 101-104. 
Satish, U., Streufert, S., Marschall, R., Smith, J.S., Powers, S., Gorman, P. \& Krummel, T. (2001). Strategic management simulations is a novel way to measure resident competencies. American Journal of Surgery 181: 557-561.

Saunders, M. \& Machell, J. (2000). Understanding emerging trends in higher education curricula and work connections. Higher Education Policy 13: 287-302.

Scally, G. (1996). Public health medicine in a new era. Social Science \& Medicine 42(5): 777-780.

Smith, A., Giles, M., Whitfield, M. \& Hind, D. (2002). Defining generic public health skills. The context and the literature. Zdrowie Publiczne 112(2): 156-161.

Sommer, A. \& Akhter, M.N. (2000). It's time we became a profession. American Journal of Public Health 90(6): $845-846$.

Sorensen, A.A. \& Bialek, R.G.E. (1991). The Public Health Faculty/Agency Forum: Linking Graduate Education and Practice: Final Report. Gainesville, FLA: Bureau of Health Professionals, Health Resources \& Services Administration and Public Health Practice Program Office, Centers for Disease and Control and Prevention.

Stasz, C. (2001). Assessing skills for work: two perspectives. Oxford Economic Papers 53(3): 385-405.

Van Beek, K.W.H., Koopmans, C.C. \& Van Praag, B.M.S. (1997). Shopping at the labour market: a real tale of fiction. European Economic Review 41(2): 295-317.

Wright, K., Rowitz, L., Merkle, A., Reid, W.M., Robinson, G., Herzog, B., Weber, D., Carmichael, D., Balderson, T.R. \& Baker, E. (2000). Competency development in public health leadership. AJPH 90: $1202-1207$. 